\title{
Boron content of Lake Ulubat sediment: a key to interpret the morphological history of NW Anatolia, Turkey
}

Kazancı N..$^{*}$, Toprak, Ö. ${ }^{2}$, Leroy S. A. G. ${ }^{3}$, Öncel S. ${ }^{2}$, Ileri Ö. ${ }^{4}$, Emre Ö. ${ }^{4}$, Costa P. ${ }^{3}$, Erturaç, K. ${ }^{5}$, McGee E. ${ }^{6}$

1 Department of Geological Engineering, Faculty of Engineering, Ankara University 06100 Besevler, Ankara, Turkey Fax: +90-312-215 0487, e-mail; Nizamettin.Kazanci@eng.ankara.edu.tr

2 Gebze Institute of Technology, 41400 Gebze, Kocaeli, Turkey. Fax: +90-262-653 8490, e-mails:, ozlemtoprak34@mynet.com (TÖ), soncel@gyte.edu.tr (ÖS).

3 Department of Geography and Earth Sciences, Brunel University, Uxbridge, Middlesex UB8 3PH, (West London), UK. Fax: +44-1895- 269 736, e-mail: Suzanne.Leroy@brunel.ac.uk, pedrojmcosta@ hotmail.com

4 General Directorate of Mineral Research and Exploration, 06520, Ankara, Turkey. Fax: +90-312-2879188, e-mails: Ozden@mta.gov.tr (IÖ), emre@mta.gov.tr (EÖ)

5 Istanbul Technical University, Eurasia Institute of Earthsciences, Maslak, Istanbul, Turkey, e-mail: erturac@itu.edu.tr

6 Environmental Radiation Research Laboratory, Department of Experimental Physics, University College, Dublin 4, Ireland, mcgee_eddie@yahoo.co.uk

\begin{abstract}
Freshwater Lake Ulubat (c. $1.5 \mathrm{~m}$ deep and c. $138 \mathrm{~km}^{2}$ ) receives sediment from a $10.414 \mathrm{~km}^{2}$ area in the seismically active Susurluk Drainage Basin (SDB) of NW Turkey. The B and trace element contents of the lake infill seem to be a link between the fresh landforms of the SDB and the lacustrine sediment. Deposition in Lake Ulubat has been $1.60 \mathrm{~cm} . \mathrm{a}^{-1}$ for the last 50 a according to radionucleides; however the sedimentation rate over the last millennium was $0.37 \mathrm{~cm} . \mathrm{a}^{-1}$ based on ${ }^{14} \mathrm{C}$ dating. The $\mathrm{B}$ content of the lacustrine infill displays a slight increase at $0.50 \mathrm{~m}$ and a drastic increase at $4 \mathrm{~m}$ depth occurring $c .31 \mathrm{a}$ and c. 1070 a ago respectively. Probably the topmost change corresponds to the start of open mining in the SDB and the second one to the natural trenching of borate ore-deposits. These dates also show indirectly a $1.4 \mathrm{~cm} . \mathrm{a}^{-1}$ erosion rate during the last millennium as the borate beds were trenched up to $15 \mathrm{~m}$. By extrapolation, it is possible to establish that the formation of some of the present morphological features of the southern Marmara region, especially river incision, began in the late Pleistocene, and developed especially over the last $75 \mathrm{ka}$.
\end{abstract}

* Corresponding author 


\section{Introduction}

The basic constituents of landforms are slopes and valleys, particularly in mountainous regions. Their formations are controlled by various and commonly immeasurable factors such as climate, tectonism, rock type, altitude and slope stability (Chorley et al., 1984; Leopold et al., 1995). The concept of erosion-sedimentation balance and denudation rate are key instruments to describe the geological-geomorphological development of a region (Einsele, 1992; Einsele and Hinderer, 1998). Obtaining an age on the formation of a landform is an aim rarely achieved. Trace elements may become keys to link parent rocks and sediments derived from them (Engstrom and Wright, 1984; Bilali et al., 2002). In the Susurluk drainage basin (SDB) of NW Anatolia in Turkey, B-bearing sequences of Neogene age have been trenched naturally and have produced Brich sediment downstream in lacustrine basins and in the Sea of Marmara (EIE, 1996) (Fig. 1). The detection and the dating of B and other elements within the lake sediment are suggested as good tools for the explanation of some Holocene geological events including erosion rate, tectonism and modern drainage. Already, the Late Holocene erosion of this region has been interpreted based on sedimentation rates and modern sediment loads into lakes Manyas and Ulubat and into the shelf of the Marmara Sea (Kazanc1 et al., 2004). Moreover, pollen assemblages within the sediment sequences of the same lakes have reconstructed the palaeo-botany and climatology of the area (Bottema et al., 2001; Leroy et al., 2002). In this study, the B and some of the trace element contents of sediment of Lake Ulubat that receives water and sediment from a B-rich drainage basin is investigated to find a possible relationship between the lacustrine sedimentation and the presentday landscape morphology in N-W Anatolia (Figs 1, 2).

Boron is a trace element being found at a concentration $10 \mathrm{ppm}$ in the crust, with average concentrations of $100 \mathrm{ppm}$ in shale, $15 \mathrm{ppm}$ in granite and $5 \mathrm{ppm}$ in basalt respectively. Its concentarions in sea water is $4.4 \mathrm{mg} / \mathrm{l}$. Boron is a useful element for provenance studies as it reflects B-bearing parent rocks. In the study area (i.e. SDB), these parent rocks form lithostratigraphic units containing a layer of B ore-deposits with high economic value. Presently, B ore and/or borate deposits are being eroded since deep alluvial trenches / valleys cut these layers. Consequently, it is expected that the B concentration of the lacustrine sediment derived mostly from the same area would change through time. The hypothesis is that a possible dating of the changes in B-content through the lacustrine sediment sequence provides the timing of fluvial 
trenching in the drainage basin. It is for this purpose that the B content of the sediment of Lake Ulubat has been studied.

\section{Figure 1}

\section{Background}

\subsection{Geological setting}

The southern Marmara region mostly comprised of the Susurluk Drainage Basin (SDB) has had a complex geological evolution since Early Palaeozoic times. Some of the oldest tectonic units of Turkey e.g. the Uludağ massif (in the east), the Menderes massif (in the south of SDB) and also old crystalline rocks are found in this region. They have formed high topographies due to the effect of neotectonism since the Neogene (Emre et al., 1998). However, in the same time period, many continental, mostly lacustrine, basins were formed and their infill is now being subjected to erosion.

Lake Ulubat, a crucial part of the study area, is located on the eastern side of a large W-E tectonic depression formed at the transition of the transform North Anatolian Fault (NAF) zone and the extensional tectonic regime of western Anatolia (Emre et al., 1997a) (Fig. 1). This depression, called the Manyas-Karacabey depression, is tilted towards the east where Lake Ulubat ( $2 \mathrm{~m}$ asl and a surface area of $138 \mathrm{~km}^{2}$ ) is located. Lake Ulubat controls the drainage of an important part of the SDB (Fig. 1). The origin of the modern lakes, including Lake Ulubat, is still relatively uncertain, but it is thought that they began through channel damming of a meandering stream system, possibly during a period of mid Holocene sea level increase (Emre et al., 1997b; Leroy et al., 2002). Some abrupt changes of sedimentary features within the infill of Lake Manyas might be related to regional seismicity and even tsunamis from the Marmara Sea (Leroy et al., 2002).

\section{Figure 2}

The stratigraphy of the Susurluk drainage basin is fairly complex and various rocks are exposed (Yilmaz et al., 1990; Okay et al., 1991). Volcanics, clastic sedimentary rocks, clayey limestones and evaporites of Late Tertiary age and, to a lesser extent, older metamorphic rocks outcrop in the 
higher parts of this basin (Yalçınkaya and Avşar, 1980). However, collated borehole data have established that the lakes are surrounded by large areas of Holocene alluvial deposits and also by some Pleistocene fluviatiles in the lower parts of the drainage basin (Kazanc1 et al., 1997; 1998). Lake Ulubat, however, is closely surrounded by karstified limestones of Mesozoic age in the east. Sedimentary and volcano-sedimentary rocks of Neogene, mostly Miocene, age form extensive units in the drainage area. These rocks provide a relatively low topography that has been incised by many medium-deep valleys. The highly elevated parts and the far southern part of the drainage basin consist of very compacted pre-Neogene rocks where river courses form a nearly rectangular drainage pattern as they generally follow fault lines (Fig. 1). Loose and sand-dominated alluvial deposits of Late Pleistocene-Holocene age were formed in the western side of Lake Ulubat with thicknesses up to $40 \mathrm{~m}$, just south of Mustafakemalpaşa town (Emre et al., 1997b). Most of the Neogene rocks in the south are composed of volcaniclastics, lacustrine limestones and intercalations of tuffs, lava flows and marl layers. These units include zones enriched of B and As apart from some pure borate beds hosted in a lacustrine succession with volcanic intercalations (Helvacı and Firman, 1977; Yalçınkaya and Avşar, 1980). In addition, the southern Marmara region contains the largest borate reserve of the world (Polat, 1976). According to the information available, c. $54 \%$ of the world borate reserve is in Turkey and of that, $80 \%$ is found in the SDB (Helvac1, 1984). More details about the B-bearing rocks are given in section 4.1.

\section{Figure 3}

\subsection{The basic morphology of the Susurluk drainage basin}

The main morphological element of the SDB and, indeed, of the whole of NW Anatolia, is one of deep fluvial valleys (Figs 1, 3 - 4). Some of these valleys have been initiated by active faults (Şaroğlu et al., 1992). Lake Manyas $\left(150 \mathrm{~km}^{2}\right)$ and Lake Ulubat $\left(138 \mathrm{~km}^{2}\right)$ are not only the source of fresh water for the region but also act as secondary base levels for local streams (Fig. 1). The main rivers are the Kocaçay River $(162 \mathrm{~km})$, the Simav/Susurluk River $(321 \mathrm{~km})$, the Emet River $(278 \mathrm{~km})$, the Orhaneli River $(276 \mathrm{~km})$ and the Nilüfer River $(172 \mathrm{~km})$ as well as their tributaries. The rivers Emet and Orhaneli form the River Mustafakemalpaşa by joining each other $45 \mathrm{~km}$ south of Lake Ulubat (Fig. 1). All the rivers join near the town of Karacabey and form the River Kocasu just before discharging into the sea (Fig. 1). 
Table 1 shows the general morphological characteristics of the main SDB Rivers. In general, lowland areas with altitudes of 350-600 $\mathrm{m}$ are predominant in the SDB. In other words, the SDB consists of extensive (2/3) lowland areas and to a lesser extent (1/3) hilly, upland areas (Fig. 1). The prominent mountains of the southern Marmara region are Uludağ $(2543 \mathrm{~m})$ to the north, Akdağ $(2089 \mathrm{~m})$ to central south and Şaphanedağ $(2120 \mathrm{~m})$ to the S-SE (Fig. 1). The longitudinal profile of the river Emet and the dips of rivers display both the general features of valleys and the erosion potential of the region (Fig. 3, Table 1).

Table 1

An intense drainage network is developed in the upper part of the SDB (Fig. 4). In addition, many valleys over $200 \mathrm{~m}$ deep have formed in the upper, mid- and lower sections of the area. The slopes of the valleys are generally not smooth indicating a fresh morphology. A step-like development in the profile of the river MKP / the Emet Stream may suggest a rapid incision of the borate-bearing succession (Figs 3, 4).

In the SDB modern agriculture is fairly effective and so an extensive sylviculture combined with a natural plant cover has developed. A relatively humid climate gives rise to both the persistence of this vegetation and to fluvial winter erosion. At present, the region is very open and intensively farmed. However, some forested areas form patches on hills above an altitude of $500 \mathrm{~m}$ combined with cultivated plants with beech and fir on the mountain tops (Quézel and Barbéro, 1985). Akdağ $(2089 \mathrm{~m})$ to the west of the town of Emet, Şaphanedağ $(2120 \mathrm{~m})$ just on the hydrologic boundary of the SDB and Uludag $(2543 \mathrm{~m})$, south of the city of Bursa are typical forested, fir and pine-dominated, mountains with barren tops in the region (Fig. 3). The latter, Uludağ, is the highest summit of NW Anatolia and it receives snow in early autumn.

\section{Figure 4}

Figure 5

\subsubsection{The MKP River}

The MKP River is the largest stream that discharges into Lake Ulubat. It is formed by two main branches, the Emet Stream and the Orhaneli Stream (Fig. 1). Sometimes, not in this study, the name of the MKP River is applied to the Emet Stream. Its main and longest branch, the Emet Stream $(278 \mathrm{~km})$, starts from the limit of the drainage basin, at an altitude of c. $1250 \mathrm{~m}$. The 
surface dip of its longitudinal profile is maximal within the first $30 \mathrm{~km}$ and its mean dip $1.1 \%$ (Table 1) (Fig. 3). The river valley is generally steep-sided (Figs 3, 4). It carries $126 \times 10^{6}$ tons of sediment load annualy reflecting high rates of denudation (Kazanc1 et al., 2004). It is typical that the load and the water compositions of the Emet and Orhaneli branches of the MKP River are similar except for their boron content. The high volume of the latter in the Emet Stream reflects a clear derivation from the Emet borate bed (Tables 4, 5).

\subsubsection{Lake Ulubat}

Lake Ulubat at the eastern end of the Manyas-Karacabey depression has a maximum water depth of $2.50 \mathrm{~m}$ and a surface area of c. $138 \mathrm{~km}^{2}$ according to Landsat TM images of May 1987 (Fig. 2), but $119 \mathrm{~km}^{2}$ to Landsat ETM of July 2000 (database; http://glcfapp.umiacs.umd.edu:8080/esdi/index.jsp). The average water depth is $1 \mathrm{~m}$ in summer and $1.50 \mathrm{~m}$ in winter. The annual fluctuations of the water level have been controlled since 1990 (Kazanc1 et al., 1998). The water surface of the lake is only $2 \mathrm{~m}$ above sea level; however the distance is c. $23 \mathrm{~km}$ from the Marmara Sea along the lake's outlet (via the Karacabey gorge). It is an open, eutrophic freshwater lake with an elongated shape $(23 \mathrm{~km} \mathrm{E-W}$ long and $12 \mathrm{~km} \mathrm{N-S}$ wide). Its periphery is irregular owing to fault scarps in the SE, old karstic features in the NE and delta progradation in the SW. Four islands of Mesozoic limestones delineate two main sub-basins called the Western Basin and the Eastern Basin that influence water and sediment circulations (Fig. 2). Other islands consist of sediment deposited after the formation of the lake. The main water and sediment sources of Lake Ulubat are the Mustafakemalpaşa River (MKP) that has an overall drainage area of $c .10,414 \mathrm{~km}^{2}$. The delta of this river rapidly progrades into the lake from the S-W to the S-E and it has shifted towards the SE probably under tectonic control (Fig. 2). The suspended sediment load of the MKP River has been about $1.3 \times 10^{6}$ ton. $^{-1}$ in the last 30 a therefore providing a sedimentation rate of $1.6 \mathrm{~cm} . \mathrm{a}^{-1}$ (Kazanc1 et al., 2004).

\section{Data acquisition and analytical methods}

Since the methods of study have been given previously in detail (Leroy et al., 2002; Kazanc1 et $a l .$, 2004), only a short summary is given here.

Some of the limnological characteristics of Lake Ulubat were surveyed in 1997 and in 2002. Modern sediment samples taken by an Eckman grab from 36 localities of the lake bottom were 
examined by routine sedimentological methods. During the survey in 2002 the water of the lake and its surrounding were sampled. A coring campaign, using PVC $63 \mathrm{~mm}$ diameter pipes and also a hand-pushed Livingstone piston corer operated from a raft, retrieved a series of $5 \mathrm{~cm}$-diameter sediment cores, in $1 \mathrm{~m}$ sections with core labels AK02 at 11 sites and the longest core, which reached $7.8 \mathrm{~m}$ depth, is at the centre of the eastern basin of the lake. Sampling at stations 1 to 5 (Fig. 2) was done by $2 \mathrm{~m}$ long PVC pipes (AK02PVC 1-5), at the others (AK02LV 6- 11) by the Livingstone-corer. The results to be presented in this study are from detailed analyses of core AK02PVC-4 (length; $190 \mathrm{~cm}$ ) in station 2 and core AK02LV-10 (length: $7.8 \mathrm{~m}$ ) in station 11 (Fig. 2). In 2004, a second coring campaign concentrated on the centre of the eastern basin and collected core from 6 to $9.7 \mathrm{~m}$ depth (core labels AK04).

Sediment concentrations in ${ }^{137} \mathrm{Cs},{ }^{210} \mathrm{~Pb},{ }^{214} \mathrm{~Pb}$ and ${ }^{214} \mathrm{Bi}$ to be used for the age interpretation were determined in homogenised sub-samples using high-resolution gamma spectrometry employing a Ge well-type detector (see Leroy et al., 2002 for detail). Two levels were dated by the AMS ${ }^{14} \mathrm{C}$ method in Poznan, Poland. The calibration was obtained by the Oxcal software (Bronk Ramsey, 2001) using atmospheric data from Stuiver et al. (1998). A relative chronology taken from the literature (Bottema et al., 2001), has been used for correlation.

Loss-on-Ignition data were obtained by the combustion of $5 \mathrm{~cm}^{3}$ sediment samples in a furnace at $550{ }^{\circ} \mathrm{C}$ and $950{ }^{\circ} \mathrm{C}$. Percentages are calculated on dry sediment with organic matter, carbonate and residual ashes forming $100 \%$. The mineralogy of the sediment is based on optical, XRD and XRF analyses. Grain size analysis has been obtained by an automatic grain-size analyser with laser (Malvern Instruments, Mastersizer 2000 model). Sieving for fossils (such as seeds and ostracods) on 75 - $125 \mathrm{ml}$ sediment samples was achieved through 500, 125 and $63 \mu \mathrm{m}$ mesh sieves after soaking in sodium pyrophosphate. The density, plasticity and porosity of bulk sediments were found by routine methods (Bowles, 1992). B and some other trace element contents of the lacustrine sediments were determined by the method of AAS with a graphite furnace using a Perkin Elmer Simaa 6000. For these analyses, samples were first dried and ground and then treated with a series of acids: $2 \mathrm{ml} \mathrm{H}_{2} \mathrm{SO}_{4}+2 \mathrm{ml} \mathrm{HNO}_{3}+0.5 \mathrm{ml} \mathrm{HF}+1 \mathrm{ml} \mathrm{HCl}$. Later on, they were dissolved with the help of an ETHOS 1600 microwave. Some critical results e.g. sharp increase and/or decrease of the B content in the cores were checked at least 3 times and their average was accepted. 
Water chemistry and suspended sediment load of rivers in the SDB have been regularly monitored by a state office (EIE). Hence some results were provided from this office. The regional morphology has been observed from 1972 to 2000 and re-interpreted by successive satellite images. The data used for valley profiles and topography are SRTM (shuttle radar topography mission) associated with a DEM (digital elevation model) with $90 \mathrm{~m}$ pixel resolution of C-Band SAR (see http://www2.jpl.nasa.gov.srtm for further technical information). The DEM data have been analysed by River Tools of ErMapper 6.3 and photo-maps have been produced by ArcMap 8 (Figs 3, 4).

\section{Results}

\subsection{Fluvial valleys and the borate-bearing Neogene sedimentary succession of the Susurluk drainage basin}

In the study area, fresh and/or young valleys are the main component of the morphology in the upper part of drainage basin (Fig. 4). The most southern part of it, south of the line KütahyaBalıkesir where the streams rise, is the main erosive area (Fig. 1B). The main stream valleys are c. 100-250 m deep and most of them are associated with fault lines (Figs 1, 3, 4). Transverse profiles of the valleys show irregular slopes; some have "V" shapes, others have "U" ones (Fig. 4). The length of secondary valleys varies from a few tens to a few hundreds of meters reflecting a relatively erodible lithology. Summits of ridges between valleys are so sharp that many captures could happen in the near future (Figs 3, 4). Short but deep valleys, captures and intense drainage network generally result from lithology-controlled, extensional erosion (Howard, 1967; Chorley et al., 1984; Leopold et al., 1995).

The most common lithology of the SDB is the borate-bearing Neogene succession. It is intercalated with volcanic and volcaniclastic rocks, overlying Palaeozoic metamorphic rocks. The succession consists of different lithologies (subunits) with different colours. They are as follows in ascending order (Helvacı and Firman, 1977); a) conglomerate and sandstone, b) marl and limestone with a tuff layer (lower limestone), c) volcanites, tuff and agglomerate, d) red unit formed by intercalations of coal, gypsum, conglomerate, sandstone, clay, marl and limestone, e) the borate zone with claystone, tuff-tuffite and marl, f) limestone with marl and chert bands (upper limestone), g) basalt (Fig. 5). The lower and upper limestones are relatively resistant to erosion and probably their presence has affected the initiation of the landform development. In contrast, 
borates can be dissolved easily by fresh water (Çolak et al., 2000). It is interesting that the upper 12-15 $\mathrm{m}$ of the borate zone has been eroded despite its section form, sometimes deep valleys down to $200 \mathrm{~m}$, and sometimes shallow ones down to $50 \mathrm{~m}$ (Fig. 4). However a good deal of the borate deposits in the region are exposed, some extra-high quality beds up to $100 \mathrm{~m}$ thick have been mined as open mines e.g beds of Bigadiç (I), Emet (II), Kestelek (III), Sultançayırı (IV) (Fig. 1B). The beds I and IV are in the drainage area of the Simav River of the SDB, however the Emet bed (II) and Kestelek bed (III) have been drained by the Emet and Orhaneli streams respectively. The Kestelek bed (III) is a relatively small bed mining as "an underground mine" and also it has a waste reservoir; hence there is hardly any discharge into the Orhaneli Stream. The Emet borate beds (II) have been mined since 1956 at the Espey1, Espey2 and Killik sites as underground mines and since 1960 at Hamamköy and Hisarc1k sites as open cast mines which all are aligned along the valley of the stream Emet. These mining sites are placed between the localities of profile 2 and that of profile 4 (Fig. 4). Colemanite $\left(\mathrm{Ca} \quad\left(\mathrm{B}_{3} \mathrm{O}_{4}\right)(\mathrm{OH})_{3} \cdot \mathrm{H}_{2} \mathrm{O}\right)$ and hydroborasite $(\mathrm{MgCa}$ $\left.\left(\mathrm{B}_{3} \mathrm{O}_{4}(\mathrm{OH})_{3}\right)_{2} .3 \mathrm{H}_{2} \mathrm{O}\right)$ are the predominant $\mathrm{B}$ minerals within the sediment of the Emet borate bed. Other minerals include meyerhofferite, ulexite, veatchite, tunelite, terugite, kahnite, gypsum, celestite and calcite which are abundantly found, but they are secondary minerals. The last 3 of them are not borate minerals, but they can be observed both in the same beds as crystals and as separate layers in the borate zone (Helvacı and Firman, 1977). In addition, elemental B, B minerals and some associated minerals (natural sulphur, realgar-AsS-, orpiment $\left(\mathrm{As}_{2} \mathrm{~S}_{3}\right)$ are also detected within each of the rocks of the succession (Table 2) (Helvacı, 1984; Helvacı and Alonso, 2000).

Table 2

The lithological pattern and/or the concentration of the B minerals in the borate zone are locally diverse. This means the thickness of the ore zone and the purity of the ore change in different mining sites along the Emet valley. Colemanite is found there as nodule(s), layer(s) of large crystal, or in dissemination. Table 3 shows the general case in the Hisarcik site. From here, also taking the general stratigraphy (Fig. 5) into consideration, one can conclude that the derivation of the B from the SDB was continuous, but it became concentrated when the borate zone began to erode.

Table 3 
Illite and montmorillonite are common rock-forming clay minerals of the sedimentary succession in the SDB (Ataman and Baysal, 1978). However the secondary minerals are usually an assemblage of smectite, chlorite, kaolinite and saponite in clays of the borate zone (Çolak et al., 2000). It is worth noting that all borate minerals have a wide elemental composition. In addition, Anatolian borates contain oxides and some trace elements (Table 3) (Helvac1, 1986). Previous studies suggest that the Anatolian borates have been deposited in lacustrine environments owing to evaporation during the early Neogene (c.f. Helvacı and Firman, 1977; Ataman and Baysal, 1978; Helvac1 and Orti, 1998; Helvacı and Alonso, 2000). However Table 2 show clearly that the Neogene rock succession, particularly volcanics and volcanites, include B associated with $\mathrm{Sr}, \mathrm{Li}$, As. Based on B and trace element enrichment within the volcanic rocks, the origin of the borate minerals could therefore be hydrothermal instead of by evaporation, but this debate is beyond the scope of this study.

\subsection{Present sediment and boron discharges into Lake Ulubat}

Presently, the lake is surrounded by moderate to high hills of Mesozoic limestone in the north, the east and the south. In addition the active Ulubat fault provides a steep southeastern coast (Fig. 2). Because of this morphology, Lake Ulubat receives carbonate-rich groundwater and water from springs (EIE, 1996). The MKP River is the main sediment load and water path for Lake Ulubat; it has formed a relatively large delta on the SW coast of the lake (Figs 1,2). The sediment load of the rivers and water chemistry of the rivers and lakes in the SDB have been recorded since 1935 by a state institute, the EIEI. According to the present data, the MKP River (Emet and Orhaneli streams) has a net drainage area of $c .8480 \mathrm{~km}^{2}$ and its average sediment load is almost $1.26 \times 10^{6}$ ton. $\mathrm{a}^{-1}$ (EIE, 1993; 2000). This means that each $\mathrm{km}^{2}$ of the drainage area of the MKP River produces 148 tons of sediment and $167 \mathrm{~m}^{3}$ of water annually. This is a relatively high rate of denudation (Kazanc1 et al. 2004). From station 331on the Orhaneli Stream in addition to station 302 on the MKP River (Fig. 1), calculations of the total, monthly and annual quantities of B discharged into lake Ulubat are possible individually for each stream (Tables 4 and 5) (Note the positions of stations 302 and 331; Fig. 1). The B has mainly been provided to the lake by the Emet Stream, particularly in summer when the air temperature is relatively high and open cast mining is intense. This is usually due not to only mine waste and wastewater, but also to dewatering of the 
groundwater in the mining sites, despite the presence of some water purification system around the mines. The long-term B values of the Kocasu River from station 317 are lower than those of stations 302 and 316, although station 317 is the last one, or a collector, based on its position (Table 5, Fig. 1). From here it can be concluded that a good deal of elemental B is caught in the lake water and lake sediments.

\section{$\begin{array}{lll}\text { Table } 4 & \text { Table } 5 & \text { Table } 6\end{array}$}

Table 6 shows the B content in the lake water. Boron is high everywhere, particularly close to the active delta (Fig. 2, Table 6). It is also worth noting that the drinking water of the Gölyazı village (NE of the lake) obtained from ground water (sample 23) and a thermal water (sample 20; on the Ulubat Fault and out of Figure 2) include a relatively high content of B (Table 6), proving that not only the surface water and the sediment but also the subsurface water has been polluted. Results from a sample from the outlet (sample 26) show relatively very high B content (Table 6). It displays also that outflow from the lake reduces the accumulation of this pollutant.

\subsection{Lacustrine pre-modern sediments}

\subsubsection{Thickness}

In Lake Ulubat, the 2002 and 2004 coring campaigns concentrated on the eastern sub-basin of the lake (Fig. 2). A series of 13 short cores (1 to $1.9 \mathrm{~m}$ ) was taken in a transect from the north to the south. A series of 12 longer cores $(5-7.8 \mathrm{~m})$ was obtained along the SE shores of the lake (Fig. 2). The longest core obtained in 2002 by hand pushing could not penetrate further than $7.80 \mathrm{~m}$ depth because of a partly compacted hard layer. Bottema et al. (2001) took a $7.2 \mathrm{~m}$ long core in 1988 in the delta (western basin). Their coring stopped on a thick sand layer (the bottom $33 \mathrm{~cm}$ ). Another coring campaign in 2004 provided sediment cores from the centre of the eastern basin down to $10 \mathrm{~m}$ depth; even if the bottom, c. $1.5 \mathrm{~m}$ was a hard layer. There are no signs that the bottom of the lacustrine infill has been reached. However, some indirect data, e.g. Holocene channel-fills nested into Pleistocene sediment of the Manyas-Karacabey depression, suggest that the Ulubat lacustrine infill could be around $10 \mathrm{~m}$ (Emre et al., $1997 \mathrm{a}, \mathrm{b}$; Kazanc1 et al., 1997; 1998). 


\subsubsection{Sedimentation rate and age-depth model}

The present results in this study which were obtained by two different methods of radiometric dating using the cores of campaign 2002 have shown larger sedimentation rates than those of previous studies (i.e. Bottema et al., 2001). They are as follows (Figs 2, 6):

1) Radionucleides: They have been studied on two cores: AK02 PVC4 (near the village of Apolyontköy = Village Gölyazı) and AK02LV12 (south of the larger island in the southern basin) (Fig. 2). The latter core is in the same station, Station 11, as LV10 and LV 11 where most of the analyses have been made.

For AK02 PVC4, the ${ }^{210} \mathrm{~Pb}$ indicates a sedimentation rate of $1.6 \mathrm{~cm} \cdot \mathrm{a}^{-1}$, whereas that of the ${ }^{137} \mathrm{Cs}$ is $1.48 \mathrm{~cm} \cdot \mathrm{a}^{-1}$ (Fig. $6 \mathrm{~A}, \mathrm{~B}$ ). Because the values of ${ }^{210} \mathrm{~Pb}$ are low, the rate provided by ${ }^{137} \mathrm{Cs}$ is considered as the best. For core AK02LV12, the values of ${ }^{210} \mathrm{~Pb}$ are too low to be reliably used. In addition, the scattering of the data does not allow deriving a sedimentation rate. However the ${ }^{137} \mathrm{Cs}$ shows well pronounced peaks for both Pacific weapon testing (1964) and the Chernobyl accident (1986), suggesting a sedimentation rate of $1.79 \mathrm{~cm}^{-1}{ }^{-1}$ (Fig. $\left.6 \mathrm{~A}, \mathrm{~B}\right)$ ). The small rate difference between the two cores seems to be reasonable as the site of AK02LV12 is much closer to the river mouth than the other one (Fig. 2). As a result, it is possible to assume that the mean sedimentation rate in the eastern basin of Lake Ulubat is approximately $1.6 \mathrm{~cm} \mathrm{a}^{-1}$.

2) ${ }^{14} \mathrm{C}$ dating: Sieving of the sediment of the whole length of core AK02LV11 provided only two horizons with terrestrial material suitable for ${ }^{14} \mathrm{C}$ dating. The results of AMS radiocarbon dating are as follows (Fig. 2):

- from 624 to $614 \mathrm{~cm}$ (a mid-point of $619 \mathrm{~cm}$ ), 5 seeds, probably of Polygonum. $1612 \pm 30$ a BP (laboratory number: Poz-3638, calibration: $95.4 \%$ probability with $5.2 \%$ for AD 260-280 and 90.2\% for $A D$ 320-540),

- from 682 to $672 \mathrm{~cm}$ (or $677 \mathrm{~cm}$ ), a 14x4x1.5 mm twig-like plant remain(s). $1708 \pm 25$ a BP (laboratory number: Poz-3636, calibration: 95.4\% probability AD 250-420), 
A general sedimentation rate derived from radiocarbon dates is of $0.364-0.384 \mathrm{~cm} \cdot \mathrm{a}^{-1}$ (on

average $0.37 \mathrm{~cm}^{-1}{ }^{-1}$ ) (Figs 2, $6 \mathrm{C}$ ). So, taking into consideration this sedimentation rate and the 10 $\mathrm{m}$ depth of the 2004 campaign, formation of the cored lacustrine infill at $0.37 \mathrm{~cm} / \mathrm{a}$ would take at least $2.674 \mathrm{ka}$.

In conclusion, these results suggest that the sedimentation rate has recently dramatically increased (> 4 times) in Lake Ulubat, as the sedimentation rates obtained by both methods are different. The ages of the 50 and the $400 \mathrm{~cm}$ changes in the B curve respectively are AD 1970 and AD 932.

Figure 6

\subsubsection{Sedimentary characteristics}

The lithology of the pre-modern lacustrine sequence in all stations is typically a silty, plastic mud with a grey colour. The water content is about 37-67 \%. Grain size analysis indicates dominance in the range of 10-35 $\mu \mathrm{m}$. The volumetric ratios of sand, silt and clay along the cores are $1-5 \%, 45-80 \%$ and $25-45 \%$, respectively (Fig. 7).

The mineralogy of the sediment is relatively similar to that of the modern lake bottom mud. Loss-on-Ignition analyses on $10 \mathrm{~cm}$-interval samples of core AK02LV 10 indicate a fluctuating record with 4-17\% total organic matter and 5-14\% carbonates (Fig. 7). Organic matter increases at depths of 6-5.5 m, 3-2.25 $\mathrm{m}$ and 1-0.25 m; however, the reasons for these increases remain unclear. In contrast, the carbonate content increases when organic matter decreases and both are independent from grain size (Fig. 7). The sediment lithology at the bottom of core 2002 is similar to most of the overlying sequence; however the mean grain size is larger in the few tens of $\mathrm{cm}$ above the sharp change of organic content (Fig. 7). In parallel, the results of chemical analyses together with heavy metal composition of the lacustrine mud show a heterogeneous distribution (Toprak, 2004). By visual inspection, core AK02PVC4 appears to be finer grained than that of AK02LV-10 for the same depths, but the vertical carbonate distribution is similar. In general, the carbonate content of Lake Ulubat is relatively high. It may come from the erosion of the Mesozoic limestones in the drainage area and karstic springs originating from the limestone. However, a 
sudden increase at $4 \mathrm{~m}$ depth together with B could be related to climatic and other changes in NW Anatolia.

Figure 7

\subsubsection{Boron content of the lacustrine sediment}

Boron analyses on $10 \mathrm{~cm}$-interval sediments in cores AK02LV10 and PVC4 have been carried out (Fig. 8). From the base to the top a sharp increase or change is detected exactly at the $400 \mathrm{~cm}$ layer, with a doubling of the B content in core LV 10. Also an obvious change is seen in core AK02PVC4 at the 60-45 cm layer in spite of a slight increase at $95 \mathrm{~cm}$ (Fig. 8). The average of B concentration is $1.205 \mathrm{~g} \cdot \mathrm{kg}^{-1}$ and $0.206 \mathrm{~g} \cdot \mathrm{kg}^{-1}$ within sediments of LV 10 and PVC4 respectively. These values are obviously above the limit tolerated for natural environments (EPA, 1973), which is of $0.2 \mathrm{~g} / \mathrm{m}^{3}$. It is most probable that the clear difference between PVC 4 and LV10 is due to the greater distance to the delta and/or to the mouth of the MKP River which discharges B-bearing sediments and water into the lake.

\section{Figure 8}

The method used to describe the B content in the lake sediment does not permit to make clear whether it comes from particles or from ions directly. However, the ionic radius of B is small $(0.23$ $\mathrm{A}^{\mathrm{o}}$ ); consequently it has a strong affinity for $\mathrm{O}_{2}$. It is also found within sediments as oxides dependent on concentration, $\mathrm{pH}$, salinity, temperature and mineral types in the environment. Most of the clay minerals, particularly high magnesian clay minerals, absorb much B; so deltaic and lacustrine environments are usually rich in B. The leaching of B from soil or sediment is fairly difficult, so it accumulates there; and over time it forms compounds with some trace and heavy metal elements i.e. Li, Cu, Co, Fe, Mg, Ag, Sn, (Barnes and Barnes, 1978; Arçak et al., 2000; Toprak, 2004). Overall, apart from a suitable environment, a B-rich drainage area provides a high volume of B in Lake Ulubat. The dramatic increase at $400 \mathrm{~cm}$ interval must depend on a sudden change in the drainage basin as other circumstances seemed to have remained the same (Fig.8). 


\section{Discussion}

As mentioned above the main objective of this study is to find a link between erosion and lacustrine deposition, more specifically between $\mathrm{B}$ deposition and the development of the present landscape in the SDB. The approach adopted is the extrapolation of the B content of the sediment in Lake Ulubat to valley formation; because B is transported easily to new environments by flowing waters, particularly by perennial streams (i.e. Langmuir, 1997). Two items of data, the thickness of B-rich lacustrine sediment $(=4 \mathrm{~m})$ and the trenched part of the borate zone in the Emet valley (= $15 \mathrm{~m}$ deep) are the basis for the following interpretations.

The B content of the Emet River is relatively high in the summer months from June to September; however the discharge of the river is small, due to high levels of mining activities in summer (the role of temperature on the B content in the stream is not known). In parallel, the B content of the water of Lake Ulubat increases in summer (Table 6). Therefore, it is suggested that the B content of lake and river waters in the SDB is completely dependent on the B available from its drainage area. This is also the case for the B within the sediment of Lake Ulubat.

\subsection{Possible age of deep valleys}

According to radionucleides and to radiocarbon dates, the ages of the $0.45 \mathrm{~m}$ layer and $4 \mathrm{~m}$ layer are AD 1971 and AD 932 (= 1070 a BP), respectively. The age of the 0.95 m layer reflects the year $1955 \mathrm{AD}$ (however it is $\mathrm{AD} 1938$ if based on $1.48 \mathrm{~cm} / \mathrm{a}$ ) that the open mining started in the SDB. Considering the sensitivity of the lacustrine sedimentation to $\mathrm{B}$, the sharp increase at $4 \mathrm{~m}$ reflects the very beginning of the incision in the borate zone and/or the start of the erosion of the borate deposit. And, during this time span, borate-bearing valleys in the SDB were trenched to a maximum of $15 \mathrm{~m}$ expressing an erosion rate of $1.4 \mathrm{~cm} \cdot \mathrm{a}^{-1}$. This rate is very high in comparison to long-term erosion but it is very close or similar to short-term ones in different climatic regions (Clayton, 1998; Hinderer, 1999; Wilson et al., 2003). The present data provides an important contribution to the understanding of the trenching history in the Late Pleistocene for the valleys in the region. For instance, this erosion rate could help to obtain c. 75 ka duration for the formation of the $550 \mathrm{~m}$ deep Emet valley with a simple calculation. Calculation of the timing (75 ka) is as follows: Erosion of upper cherty limestone unit (see Fig. 5) which is at least twice resistant $=400$ $\mathrm{m} / 1 / 2$ erosion rate $=c .57 \mathrm{ka}$, plus formation of valleys of $250 \mathrm{~m}$ in the borate-bearing deposits, 250 $\mathrm{m} /$ erosion rate $=c .18 \mathrm{ka}$. 


\subsection{Possible role of tectonism on erosion}

NW Anatolia, including the Susurluk drainage basin, is still seismically active and, what is more, many valleys correspond to active fault lines (e.g. Şaroğlu et al., 1992; Emre et al., 1998). This may imply a link between erosion, lacustrine sedimentation and active tectonism. The area, particularly the southern Marmara region, has been continuously subjected to earthquakes in historical times (e.g. AD 460 at Erdek -Cyzicus-, AD 368 at Mustafakemal Paşa -Germe-, AD 447 at Marmara, AD 365 at Iznik; Ambraseys and Finkel, 1991) and the term Early Byzantine Tectonic Paroxysm (EBTP) was proposed to describe a cluster of devastating earthquakes in the period of AD 400 to 600 in the Mediterranean region (Stiros, 2001). It is also believed that the collapse of a long-lasting arboriculture civilisation in the Middle East, the Beyşehir Occupation Phase (BOP), had been related directly or indirectly with hazards of the EBTP based on the background of climatic aridification (Heim et al, 1997; Leroy et al, 2002; 2004). Many devastating earthquakes also occured during the Byzantine, Ottoman and modern Turkish Republic times (e.g. AD 715 at Iznik, AD 740 at Istanbul, AD 865 and 986 at Istanbul, AD 975, 989 and 990 Bandirma, AD 1064 at Iznik, AD 1344 and 1507 at Istanbul, 28 March 1970 at Gediz/Emet; Soysal et al., 1981; Altınok et al., 2001). In brief, the region has always been affected by tectonism, with, however, an intensity that varied over time. Meanwhile the erosion was considerable in the same region (Kazanc1 et al., 2004). Because of the high rate of Late Holocene erosion on the upland area, the coastal morphology of the Marmara Sea changed significantly. A large tectonic depression (the Manyas-Karacabey graben) was filled resulting in the formation of lakes Ulubat and Manyas and the Kocasu delta (Fig. 1). Additionally, the modern lacustrine deltas in lakes Ulubat and Manyas have been prograding rapidly (Emre et al., 1997a, b; Kazanc1 et al., 1997; Leroy et al, 2002). The subaerial morphology of NW Anatolia presently is very irregular due to fresh gullies, steep-slope valleys, and pointed hills combined with tectonic depressions forcing a tectonic interpretation for the high rates of erosion. The result pointing to this interpretation is the slope instability; the 1970 earthquake at Gediz/Emet and later on many non-devastating events showed that seismic shocks have widely caused failures of slopes and then erosion has increased significantly as recorded in different observatories (Table 5) (EIE, 2000).

\section{Figure 9}




\section{Conclusions}

Lake Ulubat is one of the important sediment traps of the Susurluk Drainage Basin; consequently its sedimentary sequence is an archive for some geological-geomorphological events. This lake, which dates back at least to the Late Holocene, has $>10 \mathrm{~m}$ lacustrine sediment transported by the river MKP. The clay mineralogy and the trace element composition of this sediment has a homogenous nature showing the Neogene volcano-sedimentary source rocks and/or that the drainage basin has remained by and large similar for the last $>2.7 \mathrm{ka}$. The main exception is the dramatic change of the B content in the sediment.

The drainage area of Lake Ulubat, in other words the Susurluk Drainage Basin, is typified by valleys; most are 200- $250 \mathrm{~m}$ deep, with a maximum of $550 \mathrm{~m}$. The region includes also a Neogene borate-bearing succession that is deeply cut by the valleys. These natural deep trenches caused the exposure of the borate beds and the derivation of B by erosion from the borate zone. Currently some of the borate beds have been trenched down to $15 \mathrm{~m}$. According to records from Lake Ulubat sediment, the first trenching of the Neogene borate bed occurred c. 1070 a ago.

The amount of trenching in the borate-bearing valleys in the drainage area of the river MKP for the last $1070 \mathrm{a}$ is around $10-12 \mathrm{~m}$, with a maximum $15 \mathrm{~m}$. It means that the erosion rate was around $1.4 \mathrm{~cm} \cdot \mathrm{a}^{-1}$. The overall sedimentation in Lake Ulubat was $4 \mathrm{~m}$ during the same time; however this rate is approximately one quarter of the erosion. Extrapolation of this erosion rate backwards and/or its use for morphology may permit estimation of the initiation time of the deep valleys in the southern Marmara region, if the chemical resistance to erosion of cherty limestone in the local stratigraphy is ignored. Consequently, supposing tectonism and stratigraphy remained similar, the modern morphology with deep valleys up to $250 \mathrm{~m}$ could be formed over a time span of $75 \mathrm{ka}$, hence in the Late Pleistocene (Fig. 9). It is also known that the climate was arid during the last glacial maximum and most of the late glacial and therefore the denudation and sedimentation rates were highly different in Anatolia (Landmann et al., 1996; Eastwood et al., 1999; Fontugne et al., 1999).

It should be remembered that the present Sea of Marmara was a relatively small but deep lake (Smith et al., 1995; Aksu et al., 1999; Çağatay et al., 2000) during the last glaciation (= latest Pleistocene), consequently the base level of the Susurluk Drainage Basin was lower. Combined with active tectonism, the elevational difference between the basin and the upland of SDB (c. 
2500-3000 m) could have played a major role in the rapid formation of the present morphology; however, this needs further data to be proven.

\section{Acknowledgements}

The present paper derives from projects supported by TUBITAK (Technical and Scientific Research Council of Turkey) and by NATO (EST.CLG.978645) on the seismic catastrophes recorded in L. Ulubat. Geological and first limnological studies were supported by a project of the National Marine Research Programme (code no: TUBITAK- YDABCAG 598/G) created by joining the State Planning Organisation (DPT), TUBITAK and the General directorate of Mineral Research and Exploration (MTA) under the coordination of Naci Görür of ITU. The lake coring campaign was funded by a NATO grant to SL and NK and partly by MTA. Sediment samples were analysed in the laboratories of Gebze Institute of Technology (GYTE) and Brunel University (BU). The manuscript benefited considerably from the unpublished MSc thesis of Ozlem Toprak, whose field work was funded by NATO CLG 978645 and was supervised by one of us (NK). A grant from the Leverhulme Trust (F00275H) to SL funded a research assistant (PC). The authors are also grateful to Etibor A.Ş. and its staff in Mustafakemalpaşa for permission to use the hostel and for their very kind hospitality respectively; to Prof. Cahit Helvacı (DEU) for providing literature and detailed information about the present situation of the mining sites; to graduate students Ediz Kirman and Fatih Uysal (A. U.) for drawing some pictures; and to Mr Huseyin (a fisherman from the village Gölyazı, Ulubat) for the use of his boat during the sampling. Dr. Mike Turner (BU) read the early version of the manuscript and improved its English considerably. Referees of the journal, M. Hinderer and an anonymous one and the associate editor M. Kersten have given very constructive suggestions. The executive editor R. Fuge made final corrections. All are acknowledged with great pleasure. 


\section{References}

Aksu, A.E., Hiscott, R.N., Yaşar, D., 1999. Oscillating Quaternary water levels of the Marmara Sea and vigorous outflows into the Aegean Sea from the Marmara Sea-Black Sea drainage corridor. Mar. Geol. 153, 275-302.

Altınok, Y., Ersoy, Ş., Yalçıner, A.C., Alpar, B., Kuran, U., 2001. Historical tsunamis in the Sea of Marmara. Internat. Tsunami Symp. 20-22 May 2001, Istanbul, Proc. 527-534.

Ambraseys, N. and Finkel, C., 1991. Long-term seismicity of Istanbul and the Marmara Sea region. Terra Nova 3, 527-539.

Arçak, S., Haktanır, K., Kibar, M., Dengiz, O., 2000. Ecological changes in Manyas Lake related to boron pollution and water regime. Proc. Internat. Symp. Desertification, TÜBITAK, June 13-17, 2000, Konya, 73-80.

Ataman, G. and Baysal, O., 1978, Clay mineralogy of Turkish borate deposits. Chem. Geol. 22, 233-247.

Barnes, M.A., Barnes, W.C., 1978. Organic Compounds. In: Lerman, A. (Ed.), Lake Sediments, Chemistry-Geology-Physics, Springer Verlag, New York, 127-147.

Bilali, L., Rasmussen, P.E., Hall, G.E.M., Fortin, D., 2002. Role of sediment composition in trace metal distribution in lake sediments. Appl. Geochem. 17, 1171-1181.

Bottema, S., Woldring, H., Kayan, I., 2001. The Late Quaternary vegetation history of western Turkey. In: J.J. Roodenberg and L.C. Thissen (Eds.)The Ilipinar Excavations II, Nederlands Instituut Voor Het Nabije Oosten, Leiden, 327-354.

Bowles, J.E., 1992. Engineering Properties of Soils and Their Measurements (4 ${ }^{\text {th }}$ Ed.). McGrawHill, Inc., NY, London.

Bronk Ramsey, C., 2001. Development of the radiocarbon program OxCal. .Radiocarbon 43, 355 363.

Chorley, R.J., Schumm, S.A., and Sugden, D.E., 1984. Geomorphology, Methuen, London.

Clayton, K.M., 1998. The rate of denudation of some British lowland landscapes. Earth Surf. Proc. Landforms 22, $721-731$.

Çağatay, M.N., Görür, N., Algan, O., Eastoe, C., Tchapalyga, A., Ongan, D., Kuhn, T., Kusçu, I., 2000. Last glacial-Holocene palaeoceanography of the Sea of Marmara: timing of last connections with the Mediterranean and the Black Seas. Mar. Geol. 167, 191-206. 
Çolak, M., Helvac1, C., Maggetti, M., 2000. Saponite from the Emet colemanite mines, Kütahya, Turkey. Clays Clay Min. 48, 409-423.

Eastwood, W. J., Roberts, C. N., Lamb, H. F., Tibby, J.C., 1999. Holocene environmental change in southwest Turkey; a palaeoecological record of lake and catchment-related changes. Quatern. Sci. Rev. 18, 671-695.

EIE, 1993. Suspended Sediment Data and Sediment Transport Amount for Surface Water in Turkey. General Directorate of Electrical Power Resources Survey and Development Administration, Spec. Pub. 87/44, Ankara (in Turkish)

EIE, 1996. Water Quality Data for Surface Water in Turkey. General Directorate of Electrical Power Resources Survey and Development Administration, Spec. Pub. 96/4, Ankara (in Turkish).

EIE, 2000. Suspended Sediment Data and Sediment Transport Amount for Surface Waters in Turkey. General Directorate of Electrical Power Resources Survey and Development Administration, Spec. Pub. 20/17, Ankara (in Turkish).

Einsele, G., 1992. Sedimentary Basins; Evolution, Facies and Sediment Budget. Springer, Berlin.

Einsele, G. and Hinderer, M., 1998. Quantifying denudation and sediment accumulation systems (open and closed lakes); basic concepts and first results. Palaegeog. Palaeoclimatol. Palaeoecol. 140, 7-21.

Emre, Ö., Erkal, T., Kazanc1, N., Görmüş, S., Görür, N., Kuşçu, I., 1997a. Neogene and Quaternary Evolution of southern Marmara Region, A project report for Turkish Scientific and Research Council (TUBITAK), YDABCAG-426/G, Ankara, 36-68, Ankara (in Turkish) .

Emre, Ö., Erkal, T., Tchapalyga, A., Kazancı, N., Keçer, M., Ünay, E., 1998. Neogene-Quaternary evolution of the eastern Marmara region, Northwest Turkey. Bull. Mineral Res. Explor. Inst. 120, 119-145.

Emre, Ö., Kazancı, N., Erkal, T., Karabıyıkoglu, M., Kuşçu, I., 1997b. Formation and geological evolution of lakes Ulubat ve Manyas. In: Neogene and Quaternary Evolution of southern Marmara Region, A project report for Turkish Scientific and Research Council (TUBITAK), YDABCAG-426/G, Ankara, 116-134 (in Turkish).

Engstrom, D.R. and Wright, H.E., Jr., 1984. Chemical stratigraphy of lake sediments as a record of environmental change. In: Haworth, E.Y. and Lund, J.W.G. (eds) Lake Sediments and Environmental History, Leicester University Press, Bath, 11-68.

EPA (Environment Protection Agency), 1973. Methods for Identifying and Evaluating the Nature and Extent of Non-point Sources of Pollutants. Publ. EPA 430/9-73-014, Washington D.C., USA. 
Fontugne, M., Kuzucuoğlu, C., Karabıyıkoğlu, M., Hatté, C., Pastre, J.F., 1999. From Pleniglacial to Holocene: a 14C chronostratigraphy of environmental changes in the Konya Plain, Turkey . Quatern. Sci. Rev. 18, 573-591.

Heim, C., Nowaczyk, N., Negendank, J., Leroy, S., Ben-Avraham, Z., 1997. Middle-East desertification: evidence from the Dead Sea. Naturwissensch. 84, 398-401.

Helvac1, C., 1984. Occurrence of rare borate minerals: veatchite-A, tunnellite, terrugite and cahnite in the Emet borate deposits, Turkey. Mineral Deposita 19, 217-226.

Helvac1, C., 1986, Geochemistry and origin of the Emet borate deposits, western Turkey. Bull. Faculty of Engineering, Cumhuriyet Univ. Serie A- Earth Sci 3, 49-73.

Helvac1, C. and Alonso, R.N., 2000, Borate deposits of Turkey and Argentina; a summary and geological comparison. Turkish J. Earth Sci. 24, 1-27.

Helvac1, C. and Firman, R.J., 1977. Geological framework and mineralogy of the Emet borate beds. Bull. Geol. Engineering 2, 17-28 (in Turkish).

Helvac1, C. and Orti, F., 1998. Sedimentology and diagenesis of Miocene colemanite-ulexite deposits (western Anatolia, Turkey). J. Sed. Res. 68, 1021-1033.

Hinderer, M., 1999. Late Quaternary and modern denudation of the Alps and implications for climate-controlled erosional processes. Tübingen Geowissensch. Arb. Series A 52, 70 71.

Howard, A.D., 1967. Drainage analysis in geologic interpretation: a summation. Bull. Amer. Assoc. Petrol. Geol. 51, 2246-2259.

Kazancı, N., Bayhan, E., Suliman, N., Sahbaz, A., Ileri, Ö., Özdogan, M., Temel, A., Ekmekçi, M., 1997. Lake Manyas and its recent sediments. In: Neogene and Quaternary Evolution of Southern Marmara Region, Report for Turkish Sci. Tech. Res. Council (TÜBITAK), Project no. YDABCAG-426/G, Ankara, 192-238 (in Turkish).

Kazanc1, N, Ileri, O., Suliman, N., Özdoğan, M., Bayhan, E., Şahbaz, A., Gencer, A, Ergin, M., Erkmen, C., 1998. Recent sedimentation in Lake Ulubat. In: Stratigraphy, Sedimentology and Morphotectonics of the Onshore and Backshore Successions at the Southern Marmara Region. A report for Turkish Sci. Tech. Res. Council (TÜBITAK), Project no, YDABCAG $-598 / \mathrm{G}, 99-145$.

Kazanc1 N., Leroy S. A. G., Ileri O., Emre O., Kibar, M., Öncel, S., 2004. Late Holocene erosion in NW Anatolia from sediments of Lake Manyas, Lake Ulubat and the southern shelf of the Marmara Sea, Turkey. Catena 57, 277-308.

Krauskopf, K., 1979. Introduction to Geochemistry. Mc Graw Hill, NY. 
Landmann,G., Reimer, A., Lemcke, G., Kempe, S., 1996. Dating Late Glacial abrupt climate changes in the 14,570 yr long continuous varve record of Lake Van, Turkey. Palaeogeog. Palaeoclimatol. Palaeoecol. 122, 107-118.

Langmuir, D., 1997. Aquous Environmental Geochemistry, Prentice Hall, NY.

Leopold, L.B., Wolman, M.G., Miller, J.P., 1995. Fluvial Processes in Geomorphology. Dover Pub., NY.

Leroy S. A. G., Kazanc1 N., Ileri Ö., Kibar M., Emre O., McGee E. and Griffiths H. I. 2002. Abrupt environmental changes within a late Holocene lacustrine sequence south of the Marmara Sea (Lake Manyas, N-W Turkey). Mar. Geol. 190, 531-552.

Leroy, S. A. G., Kazanc1, N., Schwalb, A., Costa, P., Öncel, S., İleri, Ö., Toprak, Ö., 2004, Are an early Byzanteine seismic event (recorded in Manyas-Ulubat lake sediment, NW Turkey) and the end of Beyşehir Occupation Phase linked? In:.Leroy, S.A.G and Costa, P. (Eds), Volume of Abstracts and Field Guide, ICSU Dark Nature-IGCP 490 Mauritania 4-18 January 2004 First Joint Meeting, Department of Geography and Earth Sciences, West London, UK, 90-96.

Okay, A. I., Siyako, M., Burkan, K. A., 1991. Geology and tectonic evolution of the Biga Peninsula. Bull. Turkish Assoc. Petrol. Geol. 2, 83-121 (in Turkish).

Polat, O., 1976. Inventory of the boron minerals in Turkey. Mineral Res. Explor. Inst., Ankara (in Turkish).

Quézel, P. and Barbéro, M. 1985. Carte de la végétation potentielle de la région méditerranéenne, feuille 1: Mediterranée orientale. Edition du CNRS, Paris.

Smith, A.D., Taymaz, T., Oktay,F., Yüce, H., Alpar, B., Başaran, H., Jackson, J.A., Kara, S., Şimsek, M., 1995. High-resolution seismic profiling in the Sea of Marmara (northwest Turkey): Late Quaternary sedimentation and sea-level changes. Geol. Soc. Amer. Bull. 107, 923-936.

Soysal, H., Sipahioğlu, S., Kolçak, D., Altınok, Y., 1981. Earthquake Catalogue of Turkey and its Surrounding, BC2100-AD1900. Tech. Sci. Res. Council of Turkey (TUBITAK), Project Rep. No 341, Ankara (in Turkish).

Stiros, S., 2001. The AD 365 Crete earthquake and possible seismic clustering during the fourth and sixth centuries AD in the eastern Mediterranean: a review of historical and archaeological data. J. Struct. Geol. 23, 545-602.

Stuiver M., Reimer, P.J. Bard, E., Beck, J.W., Burr, G.S., Hughen, K.A., Kromer, B., McCormac, G., van der Plicht, J., Spurk, M., 1998. INTCAL98 Radiocarbon Age Calibration, 24000-0 cal BP. Radiocarbon 40, 1041-1083. 
Şaroğlu, F., Emre, Ö., Kuşçu, İ., 1992. Active Fault Map of Turkey. General Directorate of Mineral Res. Explor. Turkey (MTA), Ankara (in Turkish).

Toprak, Ö., 2004. Heavy metal and organic matter content of sediments of Lake Ulubat (unpublished MSc thesis). Gebze Inst. Tech. (GYTE), Kocaeli, Turkey (in Turkish).

Wilson, C.G., Matisoff, G., Whiting, P.J., 2003. Short-term erosion rates from a 7Be inventory balance. Earth Surf. Proc. Landforms 9, 967-977.

Yalçınkaya, S. and Avşar, Ö.P., 1980. Geology of Mustafakemalpaşa (Bursa) area. Mineral Res. Explor. Turkey (MTA), A report, no: 6717, Ankara (unpublished) (in Turkish).

Yılmaz, Y., Gürpınar, O., Genç, S.C., Bozcu, M., Yılmaz, K., Şeker, H., Yiğitbaş, E., Keskin, M., 1990. Geology of Armutlu Peninsula and its surrounding. A Turkish report for Turkish Petroleum Company (TPAO), no 2796, Ankara (unpublished). 